\title{
Madeira urbana: \\ Uma alavanca para mudança em sistemas urbanos
}

\author{
Lauren E. L. Marshall \\ US Forest Service, National Program Manager, Urban \& Community Forestry \\ lauren.marshall@usda.gov
}

\section{RESUMO}

Por volta da virada do século, a madeira representava cerca de $17 \%$ do conjunto de resíduos enviados para aterros nos Estados Unidos. Essa categoria incluía madeira de alto valor potencial proveniente da demolição de prédios vazios e da remoção de árvores como parte das atividades de manutenção da floresta urbana. Enquanto isso, muitas cidades dos EUA estão enfrentando altas taxas de vacância e copas de árvores urbanas desigualmente distribuídas. Trabalhando com profissionais, parceiros do governo local e organizações sem fins lucrativos em Baltimore, Maryland, o Serviço Florestal dos EUA elaborou um Modelo Sistêmico de Negócios voltado à Economia da Madeira Urbana que captura o valor da madeira urbana e atrai recursos públicos e privados que podem ser reinvestidos em comunidades carentes. Em última análise, a implementação deste modelo pode contribuir para economias urbanas mais sustentáveis que permitem a recuperação de terras e a restauração de ecossistemas, promovem o desenvolvimento econômico e melhoram a vida em áreas urbanas nos EUA e no mundo. Nesta sessão, os participantes ouviram mais sobre a experiência do Serviço Florestal dos EUA em Baltimore e aprenderam como construir e sustentar uma economia da madeira urbana que atrai empresas do setor privado e promove o desenvolvimento econômico enquanto permite a restauração de terras e ecossistemas.

Palavras-chave: economia da madeira urbana, modelo de negócios, sustentabilidade.

\section{ABSTRACT}

Around the turn of the century, wood made up about $17 \%$ of waste communities sent to landfills in the United States. This stream included potentially high value wood from the deconstruction of vacant buildings and the removal of trees as a part of urban forest maintenance activities. Meanwhile, many U.S. cities are struggling with high vacancy rates and inequitably distributed urban tree canopies. Working with on-the-ground practitioners and non-profit and local government partners in Baltimore, Maryland the U.S. Forest Service has woven together a systems based Urban Wood Economy Business Model that captures the value of urban wood and attracts public and private resources that can be reinvested in distressed communities. Ultimately, implementing this model can contribute to more sustainable urban economies that enable land reclamation and ecosystem restoration, promote economic development, and improve lives in urban areas across the U.S. and the world. In this session, participants heard more about the U.S. Forest Service experience in Baltimore and learnt how to build and sustain an urban wood economy that attracts private-sector businesses and promotes economic development while enabling land and ecosystem restoration.

Keywords: urban wood economy, business model, sustainability. 